\title{
Discussion
}

Dr. K. Kato: Could you find any differences in the enzyme activity at various sites of stomach ?

Dr. S. Ohkawa : Yes, I could. There were marked differences in the activity at each sites. Therefore, I have gathered tissue materials from two sites (one from antrum and the other from corpus). When we want to get much more accurate histochemieal data, it is necessary to biopsy at least at nine different places of stomach.

Dr. Yamada : (1) Were there any significant relations between the enzyme activity and the secretion of pepsin of chief cells.

(2) Were there any possible relationships between the pepsin activity in the gastric juice and the histochemical findings of parietal cells ?

Dr. S. Ohkawa : There may not be any relations between the two.

\section{Enzyme Histochemistry of Aorta}

\author{
Akira Mizutani and Tomomasa Shindo \\ (Department of Pathology of Tuberculosis Research Institute, Kyoto University, Kyoto.)
}

There have been many biochemical studies of metabolism of the normal and atherosclerotic aorta, and some histochemical studies were also observed. However, the enzyme histochemical researches of the aorta are rare $^{1)}$. The present studies delt with the normal and pathological aortae enzyme histochemically combined with the cells which composed the tissues.

\section{Materials and Methods}

1. The human normal and atherosclerotic aortae were removed on autopsy and they were frozen with dry ice or fixed in cold formol-calcium solution as soon as possible. Of 20 cases ranging the age from 6 months old to 65 year old, the aortae were observed.

2. Rabbits : Normal adult rabbits, weighing about $2 \mathrm{~kg}$, were used. The aortae were removed just after sacrifice and frozen with dry ice or fixed. The rabbits fed with lanolin or cholesterol were also examined. Fresh frozen or cold formol fixed-frozen sections were stained for the detection of the following enzyme activities.

Dehydrogenases (Nitro-BT method)

Succinic dehydrogenase.

$\alpha$-glycerophosphate dehyrogenase.

DPN-or TPN-linked dehydrogenase systems.

lactate, iso-citrate, malate, $\beta$-hydroxybutyrate,

and glucose-6-phosphate dehydrogenase systems.

Alkaline and acid phosphatase (alk-p-ase, acid-p-ase)

Esterases 
Tween method (Tween 60 and 40)

Naphthol AS acetate method.

Phosphorylase

Leucine aminopeptidase.

\section{Results and Comments}

The human aorta, as is well known, is divided in three layers; Tunica intima, $T$. media and $T$. adventitia. These layers consist of endothelial cells, fibrous cells, smooth muscle cells and fibrous elements. However, the young human aorta and that of rabbit are not so distinctive to be devided in three layers.

\section{The results are summarized in Table 1.}

DPN- and TPN-diaphorase activities were most intensely shown in every cells of the aorta. The endothelial cells covering the inner surface of $T$. intima, fibroblasts in every layers, muscle cells especially in $T$. media, and endothels of vasa vasorum were all intensely positive in these enzyme reactions.

Other DPN- or TPN-linked dehydrogenase systems showed their activities in various grades. Generally, the endothelial cells of the innermost surface layer intensely stained by the dehydrogenase staining methods, and with the majority of dehydrogenases, the activity of muscle cells was also relatively higher. Succinic dehydrogenase activity was not prominent as that of other dehydrogenases in the endothelial layer and muscle cells.

Table 1

\begin{tabular}{|c|c|c|c|c|c|c|}
\hline \multirow[b]{3}{*}{ enzymes } & \multicolumn{5}{|c|}{ human } & \multirow{3}{*}{ rabbit } \\
\hline & \multicolumn{3}{|c|}{ adult } & \multicolumn{2}{|c|}{ child } & \\
\hline & Endothel & $\begin{array}{c}\text { Fibrous } \\
\text { cells }\end{array}$ & $\begin{array}{c}\text { Muscle } \\
\text { cells }\end{array}$ & Endothel & $\begin{array}{l}\text { other } \\
\text { cells }\end{array}$ & \\
\hline $\left.\begin{array}{l}\text { DPN } \\
\text { TPN }\end{array}\right\}$ diaphorases & $H$ & H & $H$ & $H$ & + & $H$ \\
\hline lactate $\mathrm{d}$. & $H$ & $H$ & $H$ & H & + & $H$ \\
\hline malate $\mathrm{d}$ & $H$ & H & + & + & $H$ & $H$ \\
\hline iso-citrate d. $\left\{\begin{array}{l}\text { DPN } \\
\text { TPN }\end{array}\right.$ & $\begin{array}{l}+t \\
+\end{array}$ & $\begin{array}{l}+ \\
\pm\end{array}$ & $\begin{array}{l}+ \\
\pm\end{array}$ & $\begin{array}{l}H \\
\pm\end{array}$ & $+\underset{ \pm}{\sim \pm}$ & $\begin{array}{l}+ \\
\pm\end{array}$ \\
\hline G-6-P d. & \pm & \pm & H & muscle + & & \pm \\
\hline$\alpha$-glycero d. & + & + & \pm & + & + & + \\
\hline succinic d. & + & + & + & + & \pm & + \\
\hline alk-p-ase & $+(W a$ & $\begin{array}{l}\text { ndering } \mathrm{c} \\
\text { Vasa } \mathrm{V}\end{array}$ & s \& $\&$ & & & \\
\hline acid-p-ase & + & Wanc & cells $H$ & + & \pm & \\
\hline Esteases $\left\{\begin{array}{l}(\text { Tween 60) } \\
(\text { Tween 40) }\end{array}\right.$ & \pm & - & - & - & - & - \\
\hline $\boldsymbol{\beta}$-Glucuronidase & + & + & \pm & \pm & \pm & \pm \\
\hline phosphorylase & - & \pm & $H$ & - & $\underset{H}{(\text { muscle })}$ & $H$ \\
\hline
\end{tabular}




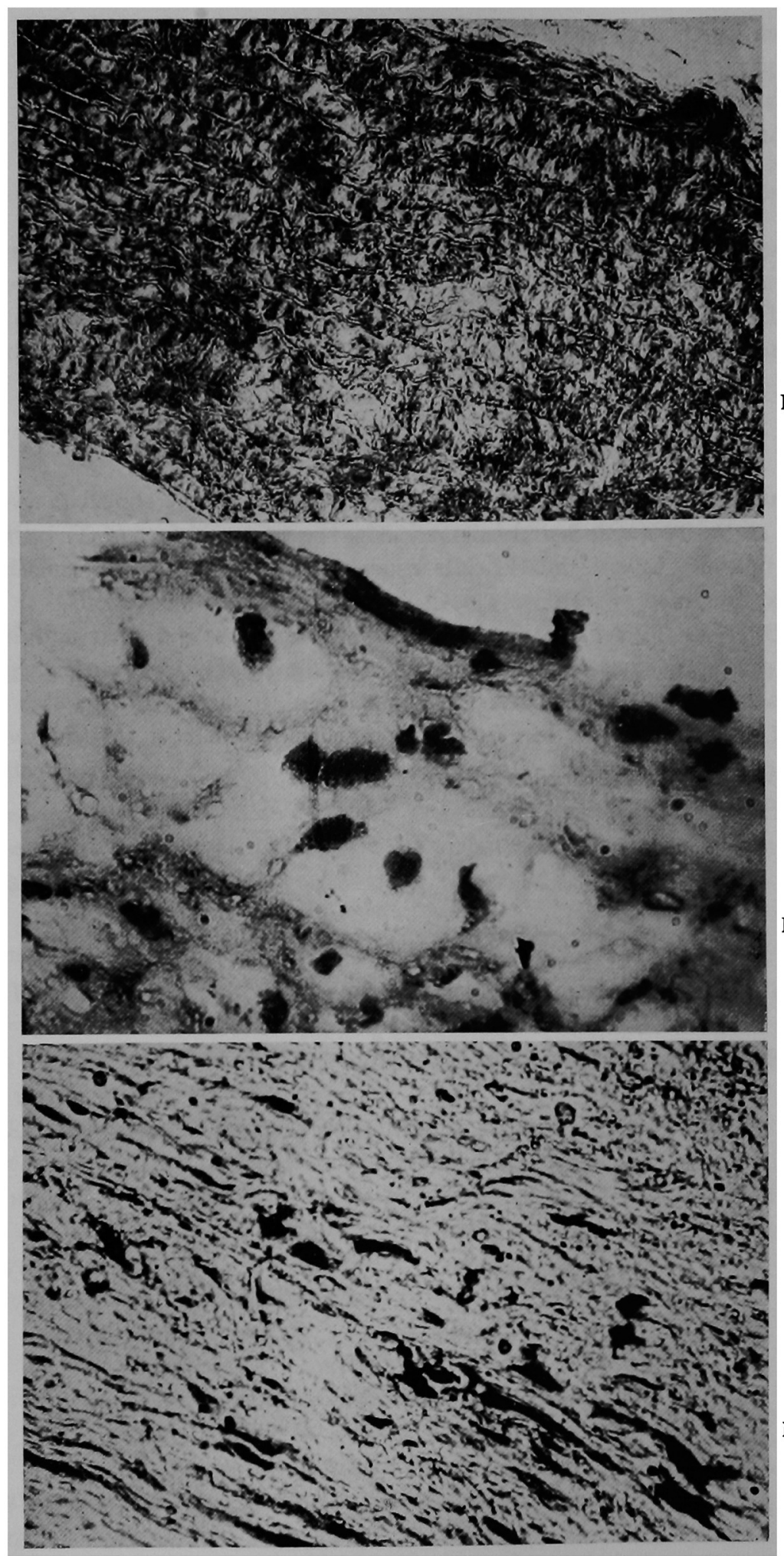

Fig. 1

Fig. 2

Fig. 3 
Some other enzymes were also demonstrated in aortic cells; alk-p-ase in arterial wall (vasa vasorum) and wandering cells, acid-p-ase in endothelial cells and wandering cells, slight lipase activity in wandering cells and endothelium, $\beta$-glucuronidase in fibrous cells, endothelium and muscle cells, high activity of phosphorylase in muscle cells, leucine- $\beta$-aminopeptidase in endothelium.

Thus, from the present results, it may be concluded that various cells such as endothelial cells, fibrous cells, muscle cells and endothelium of vasa vasorum, which compose the aortic tissue, show the various enzyme activities resemble to those of other organs, i. e. the existence of metabolisms through the glycolytic cycle, citric acid cycle and pentose cycle are well suggested in these cells. However, majority of enzyme activities tested resembled to those of rest cells in subcutaneous tissues, and the activities were generally weaker than those of sensitized cells or of granulation tissues, although some dehydrogenases such as diaphorases were remarkable in the aorta.

The atheromatous lesions of human aortae are generally lacking in most enzymes, but it must be indicated that weak activities of dehydrogenases, especially of diaphorases were still recognized in the fibrous cells of the lesions.

In experimental rabbits fed by lanolin or cholesterol, elevation or decrease of some dehydrogenase activities of the aortae which did not yet show any morphological changes were observed. However, the further studies will be necessary to discuss the pathogenesis of atherosclerosis.

\section{Summary}

The histochemical activities of dehydroenases, alk- and acid-p-ase, esterases, $\beta$-glucuronidase, phosphorylase and leucine aminopeptidase in the human and rabbit aortae were observed. The endothelium covering the innermost surface, fibroblastic cells and muscle cells in every layers, and wandering cells showed the various enzyme activities. These activities resembled those of rest cells in subcutaneous tissues and much weaker than those of sensitized cells. In addition, the findings in atherosclerotic tissues and experimental animals were reported.

\section{Explanations of plates}

1) DPN diaphorase reaction (Nitro BT method) in the human young aorta. The high activity is shown in whole layers.

2) Acid-p-ase reaction in the human adult aorta. Endothelium and wandering cells are positive (counter stained with hematoxylin).

3) DPN diaphorase activity is still shown weakly in fibrous cells of atherosclerotic lesion. 